\title{
Notes on Some Museums in Galicia \& Transilvania
}

\section{F. Haverfield M.A., F.S.A.}

To cite this article: F. Haverfield M.A., F.S.A. (1891) Notes on Some Museums in Galicia \& Transilvania, Archaeological Journal, 48:1, 1-13, DOI: 10.1080/00665983.1891.10852460

To link to this article: $h$ ttp://dx.doi.org/10.1080/00665983.1891.10852460

曲 Published online: 15 Jul 2014.

Submit your article to this journal 주

View related articles $\sqsubset$ 


\section{Archaedogical 3ournal.}

MARCH, 1891.

NOTES ON SOME MUSEUMS IN GALICIA \& TRANSILVANIA. ${ }^{1}$

BY F. HAVERFIELD, M.A., F.S.A.

In a recent number of the Journal of Philology (xvii, 274-289), I published some notes on archæological museums and remains to be seen in Carniola, Croatia and Serbia. I now venture some similar notes on local museums in Galicia and Transilvania, which I have lately visited. I do not pretend to any completeness in description or originality in comment. My own interests lie mostly in the direction of Roman remains in which the Galician museums are very poor, the Transilvanian museums fairly rich. I have endeavoured to include prehistoric remains so far as I could; concerning mediæval remains, there is neither much to say, nor do I feel qualified to say it. On the whole, it has seemed to me worth while to attempt some rough sketch of the objects contained in the museums which I was able to visit. What one really wants is, of course, a handbook, or series of handbooks, which should do for the local museums of the continent what Dr. Anderson has lately done for various Scotch collections. Meanwhile, my jottings may help archæologically-minded tourists better than the ordinary guide books do, and the very inadequacy of my descriptions may irritate more competent writers into supplying at once the needed handbooks.

\section{Cracow.}

Many tourists visit Cracow, but most of them are probably contented with inspecting the numerous churches of the city, the Kosciuszko Hill, and the neighbouring salt mines at Wieliczka. All of these are quite worth seeing-particularly the churches, which, besides other things more readily noticed, contain some fine woodcarving, and which leave one something to see even after two visits to the town. Antiquaries will find even more

${ }^{1}$ Read at the Montlly Meeting of the Institute, June 5th, 1890. VOL, XLVIII (No. 189). 
to interest them, if they examine the museums. That of Prince Czartoryski is, indeed, artistic rather than archæological, though it includes a few good Greek antiquities, but those who find the way into the museum in the University buildings, have before them an interesting collection, which is probably not so often visited as it deserves to be. In Roman remains it is, of course, exceedingly poor. I shall speak below about the extent of the Roman province of Dacia; here I may say that in Galicia very few Roman remains occur, only coins, weapons, and pottery, which have probably come over the Carpathians by way of trade. But the collection is rich in remains of the stone and bronze ages, and is the more interesting because it contains objects from all parts of Poland, Austrian, Russian, and Prussian. It is, indeed, so far as I know, the only local museum in which the early civilization of the Vistula valley can be studied as a whole. Among the pottery, the pieces which struck me most were (1) a cup of earthenware, about $7 \mathrm{in.} \mathrm{high,}$ with a very large foot, and five perforations in the bowl (No. 488); (2) an urn of about the same height, with two curious "ears" forming a handle (No. 8500); and (3) a round bellied urn, $4 \frac{1}{2} \mathrm{in}$. high, with four short legs (No. 8499). But I have no doubt more practised eyes would detect more valuable objects.

\section{Lemberg.}

Few tourists, I imagine, find their way to Lemberg. It is a badly situated town, with few objects of interest and not much natural beauty - though there is a fine view from the "Kopiec unii." The town has also at least one good hotel, rejoicing in a name familiar to Englishmen, the "Zorza," or "George." There are two museums, the Dzieduszycki museum near the theatre, and the Ossolinski National Institute, standing in grounds of its own. The former, a private museum, is usually closed in August, and as my visit to Lemberg was in that month, I was able to see very little of it. One remarkable object, however, was visible, a Slavonic (?) idol, four-faced, about 10 feet high and 15 inches square, which was found in or near the river Zbrucza in Podolia in 1848. What appeared to be the front face is in four compartments, at the top a 
male figure-down to the waist-with the arms across the body, the right arm a few inches higher up than the left; below that a horse, below that a complete figure in a sort of long jacket, and at the bottom a face. I was told that the museum also contained some gold ornaments found with the figure. The Ossolinski Institute comprises objects interesting in connexion with Polish history, portraits, coins, weapons, autographs. There are a few prehistoric remains, and one or two things which seem to be Roman, two small glass bottles (Nos. 1713, 1715) and an amphora 18 inches high with the two handles perfect (No. 171-1386), which (I was told) was found near Tarnopol, about 1868, along with skeletons, ashes, and other pottery. These are, no doubt, relics of trade.

\section{Czernowitz.}

Czernowitz, the capital of the Bukowina, is in point of situation a far more attractive town than Lemberg, but it is not otherwise a pleasant place. One interest, indeed, the town has which can hardly be matched in Europe. The Bukowina was annexed to Austria in 1775, and the capital and chief towns were garrisoned by German colonists, who have held their ground more or less completely till this day. Accordingly, here, at the meeting place of Ruthenian and Rouman, 300 miles from any Teutonic land, the astonished traveller stumbles upon a town where the streets are named with German names, and the local politicians, in the local newspapers, assault one another in the German tongue. But, though the townspeople are still, in great part, German-speaking, they have not lived in the midst of Ruthenes and Roumans for nothing, and the place struck me as being German in a limited sense. ${ }^{1}$ Things are very different in the German settlements in Transilvania, which I visited afterwards. There the "Saxons" have maintained their nationality through-perhaps, because of-the troubles which have beset them. Here the German element seems likely to merge in the surronnding populations, and the future struggle in Bukowina politics will be that between Ruthene and Rouman. In any case, the place has an interest for the student of nationalities-perhaps even for the anthropologist.

\footnotetext{
1 However, Czernowitz and Suezawa returned three German Liberals at the

recent elections for the Austrian "Reich. srath."
} 
There is no museum at present in Czernowitz. A University was founded in 1875 , some members of which have already distinguished themselves in scholarship, and Dr. Polek, of the University Library, told me that a museum was in prospect, for which collections are being made.

Here, perhaps, I may briefly discuss the question whether the Romans ever extended their frontiers over the Carpathians, that is, whether they ever permanently occupied any part of Galicia, of the Bukowina, or of Moldavia, the adjoining land southwards. Most of Transilvania was certainly included in the Roman province of Dacia; what were the north and north-east frontiers of that province? In the first place we have Ptolemy's state. ment (iii. 8) that "Dacia" was bounded on the north by the Carpathians-i.e,, the Tatra and Liptau ranges, not the whole chain - on the north-east by the Turas (Dniester), on the east by the Hierasus (Prut or Seret). If this account be taken literally, Dacia included the Bukowina, and parts of Galicia and Moldavia. Unfortunately our only other evidence-that of existing remains-does not quiet agree with this description. Roman remains -settlements, inscriptions, roads, \&c -... are abundant enough in western Transilvania, and are not unknown in the eastern part of the same country. But the Carpathians themselves - which form in many parts rather an upland forest than the abrupt rampart of our maps-have yielded little, and their north and east slopes are equally bare. Little is known of Moldavia. But Galicia, as I have said, contains only a few finds due to trade, and the Bukowina is little better off. The certain finds there ${ }^{1}$ consist of (1) a burial urn five inches high, and (2) coins found in or by an earthwork wall, near Seret, the date of which coins seems not to be known. Other reputed remains are (3) tiles found at Seret, (4), an earthwall running from the Dniester through Podolia into Galicia, and (5) a Roman camp said in the Austrian newspapers (Neue Freic Presse, \&c.) to have been found in 1886 at Hlinica, a little north of

1 See, besides some papers by Gooss : Onciul Zur Geschichte der Bulcowina (Czernowitz 1887) i. pp. 6-10, and Kaindl Geschichte der Bukowina in the Bukio. winaer Nachrichten June-July, 1888. Tocilescu Dacia inainte de Romani
(Bucuresci 1880) does not discuss the subject. There are several uncritical works whioh defend the Roman occupation e.g., Prelecz Geschichte der Stadt Scret (Sreet 1886). 
Czernowitz. Of these, the tiles are certainly post-Roman, the camp is (as I was told) pretty certainly Tartar or mediæval, and the eartliwall belongs to a whole class of earthworks ${ }^{1}$ probably resembling our English Wansdykes and Grimsdykes in construction, some of which seen to be demonstrably un-Roman, while no single one has yet been proved to be Roman. The net result is that no Roman occupation of the Bukowina can be proved from existing remains. How then shall we reconcile Ptolemy with the remains? Dr. Hodgkin (English Hist. Review, $1887, \mathrm{pp} .100-103)$ suggests that Ptolemy's Dacia may be the land of the Dacians, not the Roman province. I have made some remarks on the point elsewhere (E.H.R., 1887, pp. 734-5), but I may here point out thus much: (1) Ptolemy's account, whether based on his predecessor Marinus or not, contains such town names as Ulpicunum and Salincue and Prcietoricu Augusta : it cannot, therefore, have been taken bodily from any source earlier than Trajan's conquest (A.D. 107). (2) After the conquest, it is unlikely that the name "Dacia," the title of the prorince, would be used to denote the Dacian land, the proper Greek rendering of which is $\dot{\eta} \Delta a \kappa \iota \dot{\eta}$. As a rule, Ptolemy is fairly exact in his titles: his section on the British mainland, for instance, is not styled 'Britannia'

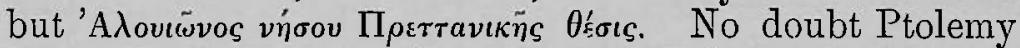
is puzzling: he omits the legions, contrary to his custom, and enumerates a row of unknown towns. Part of his account may be derived from sources earlier than Trajan; part may be comparatively untrustworthy. Two theories may be suggested to explain why his frontiers differ so much from those suggested by the remains. Firstly, they may be meant to be roughly geographical. On the north we have the mountains, where these rise to a respectable height, ${ }^{2}$ on the other three sides the river. ()r it is possible that, as I suggested in the English Historical Review, Trajan conquered the full extent described by Ptolemy, and that Hadrian withdrew from the outlying portions, as he did from Mesopotamia. Hadrian is said to have meditated giving up the province entirely, but

\footnotetext{
1 I have enumerated ten in the English IIist. Review, 1887, p. 735 . See further Hübner Romische Uerrscha/t in Westcuropa, pp. 78-82.
}

2 The Tatra range (7000-9000 feet) is the highest part of the chain which we call Carpathian ; indeed, the latter name is sometimes confined to it alone. 
the only evidence that he regulated the northern frontier is the assertion that a certain wall in the north-west resembles our Hadrian's Wall, and this assertion now seems to require further confirmation. Epigraphic evidence ${ }^{1}$ seems, however, to suggest that some places north of the Danube did not belong to Dacia. We can trace a customs-line, such as would mark a provincial frontier, shutting off Mehadia and other places lying to the S.W. of Dacia, from the Dacian administration. These places were certainly Roman, and there is further evidence to shew that they belonged to Moesia. Similarly on the S.E., a customs line seems to have run along the river Aluta or Alt, to the W. of which lay Dacia, and a fort with a Moesian garrison has been found in Wallachia, not very far S. of Kronstadt. It would follow from this that the districts in question belong to Moesia. Hence Prof. v. Domaszewski has suggested that Trajan's Dacia included them but that Hadrian transferred them to Moesia. If Hadrian altered the S.W. and S.E. frontiers, he may also have altered the $\mathrm{N}$. frontier, though here we seem to be without evidence. We have however some proof that the territory was reduced in some way, for it seems at ftrst to have been garrisoned by two legions, while afterwards one was enough.

\section{Kronstadt (Brasso.)}

Kronstadt, though rich in scenery and mediæval remains, has no proper museum, but Dr. Julius Gross was kind enough to shew me a small collection in the "Honterus Gymnasium." The chief Roman remains consist of casts of some gold ingots, minted at Sirmium and found lately in the extreme south-east of Trausilvania at Kraszna, and a hoard found in 1887 near Tartlau, about 12 miles N. of Kronstadt. Full accounts have been published of both. ${ }^{2}$ The former belongs to the later years of the fourth century A.D., the latter to the period of the Roman Republic. It comprises some 200 silver denarii, minted B.c. 217-43, and must have been buried soon after the latter date.

\footnotetext{
1 A. v. Domaszewski die Grenzen von Moesia superior (Oest. Ar'ch. Epigr. Mitth. xiii. (1890), pp. 137, 144 n. 82.

2 For the Kruszna find see Mommsen Numismatische Zeitschrift, and a note by
}

myself in the Classical Review, iii, 186. The Tartlau find has been fully catalogued by Dr. Gross, Korrespondenzblatt des Vereins fur Siebenbürgische Landeskunde, xiv. 9 (Febr., 1891.) 
Like the Frauendorf hoard, found some miles N. of Hermannstadt, it is a relic of Roman trade, not of conquest. Mediæval antiquities are better represented. Here, as elsewhere in this country, the German scholars, who form the learned class, have devoted themselves to the history of their own people, the Transilvanian Saxons. The latter, as is well known, immigrated from Germany at various periods since the twelfth century and have stubbornly maintained their national character and language. To this day they are the most important part of the population of the southern Transilvanian towns, and recent statistics have shewn that they are now in no danger of dying out. The original homes of these immigrants and the fortunes of their descendants have been worked out in detail and with great success by various scholars, notably by Dr. Teutsch. linglish students will find a capital account of this remarkable people in Mr. Boner's excellent book on Transylvania (London, 1865) and I need, here, only warn my readers that some other English books on the subject are less reliable, and that facts are sometimes distorted by race jealousy.

\section{Schässburg (Segesvar).}

Like Kronstadt, Schassburg is not a Roman site, though there appears to be a Roman road along the valley of the Kokel, in which the town is situated, and on the road there is a camp of undoubtedly Roman origin, about three miles to the north-west of the town (C.I.L., iii, 6528, Gooss Chronnk, p. 106). There is, however, in Schassburg an interesting museum, collected mainly by the exertions of the late Carl Gooss, an archæologist who did more than any other one man in Transilvania to further our knowledge of Dacia. By the kindness of Professor Fabini I was able to look through this museum, which is preserved in the rooms of the Gymnasium close to the church, overlooking the town. There is a fine collection of coins : (1) Greek silver, from Dalmatia and Macedonia, brought by traders since the second century B.c. from the Adriatic and Aegean costs; (2) barbarian silver imitations of the same, which an English antiquary naturally compares with the British imitations of Greek coins

${ }^{1}$ Metzel Archiv fur siebenbürgische Landeshinde $\mathrm{xx}$ (1886) 215-510. 
current in our islands before the Roman conquest; (3) Roman silver of the Republic, a few of which seem to have been imitated by the Dacians, and which belong to the Roman traders of the period before 100 A.D.; (4) Roman imperial coins, confined almost entirely to the reigns between Trajan and Aurelian. There were also a few late Byzantine gold coins, such as are more common south of the Danube. These four classes of coins, which space alone would forbid my enumerating in detail, are those which $i$ found to be commonest in all the collections which I saw and in the shops where I enquired. The barbaric imitations (No. 2), which are perhaps the most interesting, are now, however, rather scarce. Among the other contents of the museum are six inscriptions (all published), legionary and other tiles, and some smaller instrumentum. One of the most curious ebjects was a piece of stone from Varhely, about eight inches each way, cut like a cameo, and representing two solliers on horseback fighting, and below them two lions (?) and two dead men. The style of the sculpture resembled that of a piece I saw afterwards at Déva, both probably being native Dacian work like that figured by Tocilescu in his Dacia. There was, both here and elsewhere, in the Transilvanian museums, a noticeable rarity of the red (so-called) "Samian" ware (terra sigillatc ). I should add that, in estimating the contents of these museums, allowance must be made for the fact that nearly everything of value now goes to Pesth, where, under the judicious care of Dr. Hampel, a first-class museum has been built up.

\section{Hermannstadt (Nagy Szeben)}

Hermannstadt may be called the capital of the Transilvanian Saxons, and the museum in the Brukenthal Palace is not one to be passed over. It contains a great many (published) inscriptions, and some statuary (e.g., a Hekate), but is poorer in the smaller objects. Of "Samian ware" there were only two pieces; the lamps (one marked FORTIS, of course) were not of much interest. The Bronze and Stone ages are also fairly well represented, and there is a collection of coins not unlike that at Schassburg. The town itself is not a Roman site. The name Cibinium given by Badeker (p. 362-1887 ed.) is purely mediæval, and the 
position of Cedoniae, which some writers place here, is really unknown. But a road ran in the neighbourhood, by the side of the Aluta or Alt through the hills and the Wallachian plain to the Danube-at least, the Peutinger table and modern maps and scholars agree in saying so, and there were apparently forts along the river till its confluence with the Danube (Domaszewski Oest. arch. epigr. Mitth. xiii. 137; Gooss Chronık pp. 78, 79, 104). There was also a Roman settlement at Hammersdorf, a hamlet near Hermannstadt.

\section{Karlsburg (Gyula Fehérvár.)}

Karlsburg, once Weissenburg "the white city"-a description which still survives in its Hungarian and Roumanian names, Fehérvár and Belgrad-is most noticeable for the fine romanesque cathedral in the citadel. There are several of these churches in Transilvania-one with a well preserved west doorway at Michelsberg near Hermannstadt. But though they burst as a delightful surprise on my ignorance, these churches, are, I believe, well known to students of continental church-architecture, and I need not describe them. The local museum, such as it is, is in the Batthyaneum, inside the citadel. The contents are not numerous, a wax tablet from the gold mines, a large Mithraic stone of an ordinary type, several published inscriptions, a few pieces of pottery, water pipes, \&c. Yet the town is on or near the site of Apulum, almost the most important Roman town in Dacia, which has yielded nearly 300 inscriptions and has been thought worthy by Gooss of a special monograph. Carved and worked stones can still be seen about the town, and one or two sarcophagi were pointed out to me, and some coins produced-all, I think, second century copper. But the real centre of the Roman town lay, I believe, a little to the south.

\section{Broos (Szaszvaros.)}

The little "Saxon" town of Broos contains an interesting collection, belonging to Frl. $\nabla$. Torma. Though I was almost a total stranger, this lady received me with the greatest kindness and not only permitted me to look carefully through her museum, but also took me herself to the spot where the objects comprising it were found. 
Broos is in the valley of the Maros, and at Tordos, a little lower down the valley, the river has eaten away a portion of high bank and has thus disclosed a large amount of early remains, chiefly pottery, but including stone and bronze weapons. Some of these remains seemed to me to be undoubtedly Roman-notably some few pieces of pottery and an earthenware "fircone" about four inches high (not perfect). The latter is exactly like the larger cones carved in stone, which occur among Roman remains in many places. But the larger part of the objects were, as I thought, undoubtedly pre-Roman, and must, I suppose, be called Dacian. The remarkable thing about them is the similarity which some objects exhibit with objects of an early date, found on the Aegean coast. For instance, some of the urns had face ornaments, and there were some small clay whorls and "idols" which might almost be put beside the little figures and whorls excavated by Dr. Schliemann at Hissarlik. It is possible that we have here the traces of an early intercour sebetween Thrace and Dacia, and Frl. v. Torma has attempted, in various published essays, to connect some of the marks on her pottery, through Troy, with the East. I am not an orientalist and cannot pretend to speak on this question. So far as I could make out, objects similar to those found near Broos, had also been discovered in other parts of the same district. At Nagy-Enyed, as I was told, there is a museum with very similar contents, and in the museums at Deva, Klausenburg, and Pesth, I noted several resemblances. Probably, then, we have the relics of a culture which once prevailed throughout western Transilvania, and possibly over a much wider area. Similar "face-urns" have also been found on the lower Vistula, though they are probably later in date. There seems, however, to be no connection between the "face-urns" of Etruria and those of the Maros and Vistula. Tordos I take to have been a burial place, with remains of various dates, which perhaps (though this is conjecture) lie in strata. The annexed illustrations will, I hope, indicate roughly some characteristics of the pottery.

\section{Déva.}

Déva is a small Hungarian and Roumanian town, a lttile lower down the Maros than Broos. Here there is 
PLATE I.

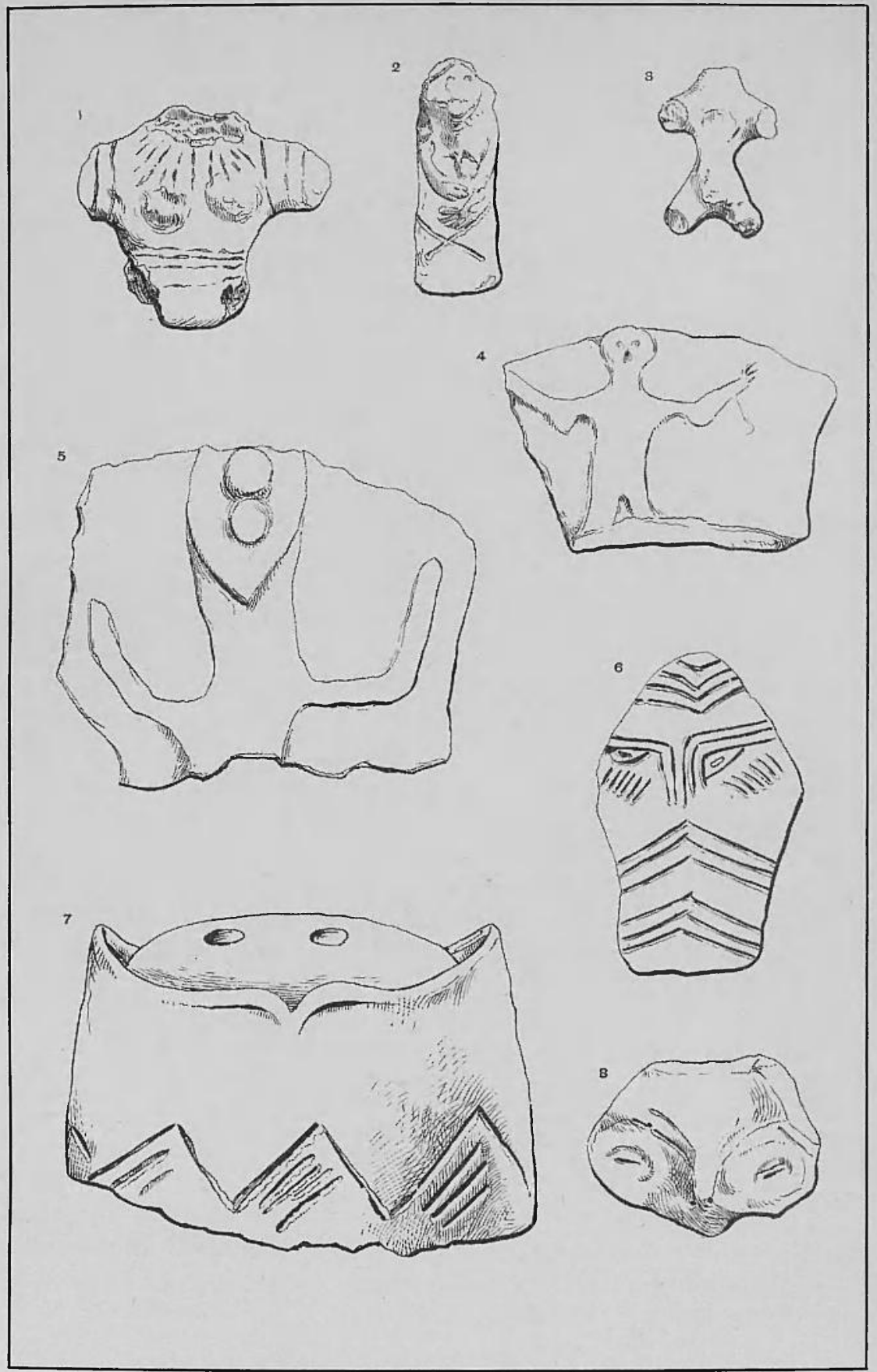

1-9, "IDOLS" OF BAKED CLAY. 4-5, BAKED CLAY FRAGMENTS WITH "IDOLS" IN RELIEF. 6, FACE ORNAMENT SCRATCHED ON ROUGH BLAOK POTTERY. 7-8, POTTERY WITH FACE ORNAMENT. BROOS COLLECTION. (see p. 10). 
PLATE H.

3<smiles>CCCCCC</smiles>
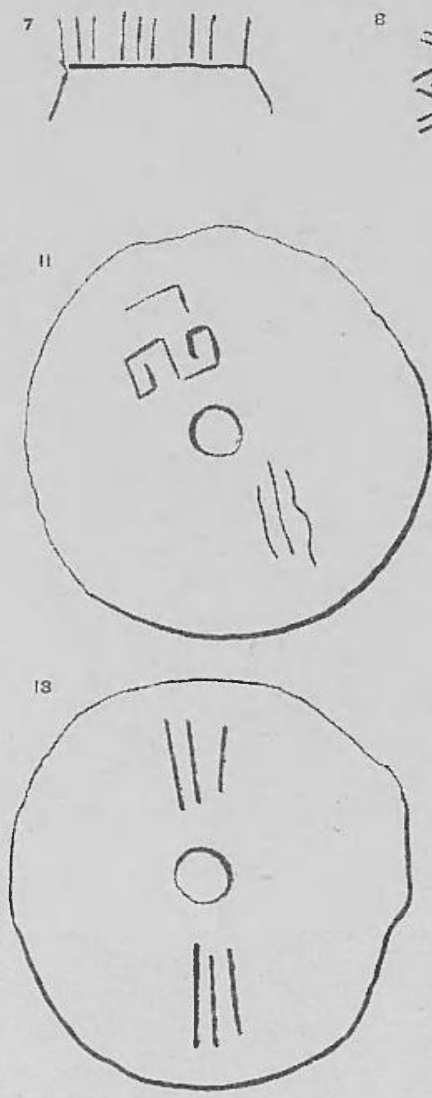

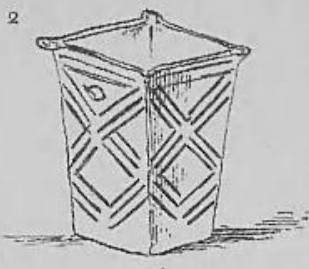

5<smiles>CC(C)=C(C)C</smiles>

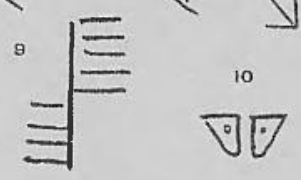

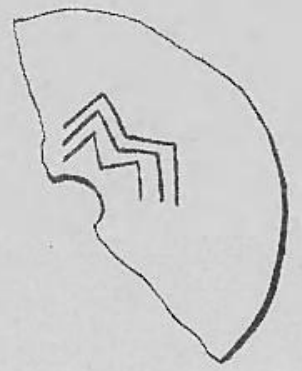

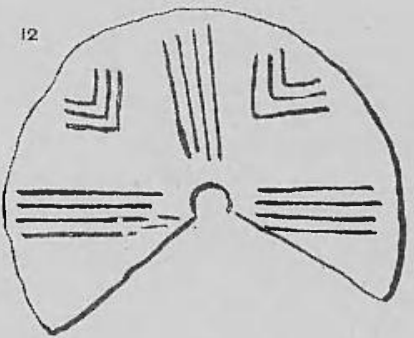

1, 2, SMALL VESSELS OF BAKED GLAY. 3-10, ORNAMENTS ON POTTERY. II-I5, OUTLINES OF WHORLS (II HALF SIZE, 12-15, QUARTER SIZE). BROOS COLLECTION, (see p. 10). 
an energetic archæological society and a good museum, under the control of Dr. Gabriel Teglas, headmaster of the "Modern School," to whose kindness and courtesy my visit owed its success. The museum consists mostly of Roman remains from the neighbourhood and from Varhely, the site of Sarmizegetusa. Among these, the most notable are the Mithraic monuments, which literally "swarm." Only one inscription was absolutely unpublished when I saw the museum, and that has been duly published since. Besides the stone inscriptions there were many tiles, a few lamps (oP'TATI, MVRRI \&c.) a little glass, hardly any "Samian" ware, and some pretty bronzes. There were also some tools from mines near, and some curious stone monuments from Korosbanya, one of the gold mines, which are supposed to be life-size figures of the miners in mining dress ${ }^{1}$. There is also a small collection of coins belonging to the museum. An adequate account of this interesting museum would, however, take up too much space, and there is the less need, as Director Teglas has informed the world of all discoveries, and a collected edition of the inscriptions is now being prepared for the Corpus Inscriptionum Latinarum by a most competent epigraphist, Professor A. von Domaszewski.

Deva is not a Roman site, but it affords a most striking instance of the difference between the Roman and mediæval ideas of a proper site for a fortress. Overhanging Deva is a steep and isolated hill of trachyte, rising up some 500 feet, and crowned by the remains of a mediæval fortress. No stronger position could apparently be found, but the Romans passed it by. Two or three miles lower down the valley, at Veczel (Micia), in the flat bottom near the Maros, they built the fort which was obviously intended to bar the passage of the valley to approach from the west. The fort was on the frontier of Dacia, and, in all probability, the land immediately to the west, which was Roman, belonged to Moesia. The camp is well preserved to this day, though the railway cuts through it and the original stone walls have gone (as I understood) to build the streets of Deva.

\footnotetext{
${ }^{1}$ Dr. Teglas has published engravings of two. See also Ungarische Revue 1884. There is very little similarity between

these mines and the remains of Roman mining in England.
} 
This instance may, perhaps, be a warning to thosethey are not unknown in England-who are accustomed to select the sites of Roman stations from their own a priori ideas of topographical fitness, and are willing, without the slightest support from existing remains, to place Roman camps on Scarborough castle hill or by Chanctonbury Ring on the Sussex downs. To such I commend the case of Deva and Veczel, as shewing conspicuously how the Romans passed by the strong hilltop and built on the flat ground near the water.

\section{Klausenburg.}

Klausenburg is one of the few "Saxon" towns which have become Magyarized. It was founded in 1178, but the colonists afterwards became Socinians, separated from the "Saxon" body, and in time became merged in the Hungarians. ${ }^{1}$ The museum, in the University buildings, was made accessible to me by Prof. Finaly and deserves a visit from any antiquarian tourist. There are a good many inscriptions, and a great quantity of smaller objects, lamps (FESTI, CASSI, FORTIS, THALLI, CAMPILI, SEXTI), pottery, and, amongst other things, a bit of Samian ware, inscribed MAXIM (the MA "tied"), fragments of mosaic, and glass. Here in fact, have been gathered nearly all the Roman remains which have been found in NorthWest Dacia and have not gone to Pesth. The net result of an examination is not unfavourable to the Roman civilisation of the district. In the East, the Roman remains do not prove anything more than a military occupation, and apparently an occupation on no imposing scale. Even the construction of the roads seems to have been below the usual Roman standard. In the North West and South West at Napoca (Klausenburg), Ampulum, and Sarmizegetusa, a richer city life displayed itself, with mosaics, statuary, "Samian " and other good pottery, and the minor ornaments of a fairly refined existence. The difference is something like that in England, between Roman London or Bath and the forts along the two Scotch frontiers. Only it must be remembered that no town in Roman Britain has produced anything like the

1 The story that householders in Klausenburg can obtain divorce easier than anyone else in Europe, is a story only.
It has, however, found its way into at least one English book on Transilvania. 
number of inscriptions which has been yielded by the three Dacian cities named. This, however, is not the place to compare Roman Britain with Roman Dacia, suggestive as such a comparison would be. For the moment, I shall be satisfied if I have made it clear that the comforts of civilization did exist in western Dacia. But how little this means will be apparent to anyone who, after seeing Deva and Klausenburg, goes on to the great museum at Pesth, and compares the ordinary comforts of Dacia with the luxurious furniture of Pannonia, the chased tripods and silver mirrors, and mother-of-pearl dishes and silver bowls which come from Savaria and elsewhere. I have not thought it needful to go into detail about either the western Dacian or the Pesth museums, partly because so much of their contents has been published in books which find their way to England, and partly because my object has been rather to direct ordinary antiquaries to objects of interest than by full descriptions to save them the trouble of visiting the museums themselves. From my own experience, I feel sure that those who may wish to do so will meet with great kindness and courtesy from those to whom they may have to apply.

For the literature of Roman Dacia the most important works are :-

1. Corpus Inscriptionum Latinarum, vol. iii., edited by Th. Mommsen. Addenda have appeared in the Ephemeris, and a supplement is in course of preparation.

2. Hirschfeld Epigraphische Nachlese (add. to o.r.t., iii.)

3. Gooss Chronik der archüologischen Funde Siebenbürgers (Hermannstadt 1876), articles in the Archiv fur Siebenbürgische Landeskunde ix-xvi., and two "programmes."

4. Articles in the Archiv by Bielz (xi., 454), Müller (xvi., 278) Werner (xix., 1), in the accompanying Correspondenablatt, in the Oesterreichische Archaeologisch-Epigraphische Mittheilungen, and in the (Hungarian) reports of the Klausenburg Arch. Society (Erdelyi Mruzeum Egylet)

5. Tocilescu Dacia inainte de Romani (Bucuresci 1880), dealing mainly with pre-Roman Dacia.

6. Jung Romer und Romanen, ed. 2. (Innsbruck, 1887).

The older works of Ackner, Neigebaur, \&c., are completely superseded by O.I.L. iii., which contains all information up to 1870 as to the history and condition of the Province.

Dr. Lissauer, Die prähistorischen Dentmäler der Provina Westpreussens (Leipzig, 1887), has thrown a good deal of light upon the early civilization of the Vistula valley and incidentally on the relations of the Broos pottery and the strme figures of Podolia.] 